\title{
ENTREPRENEURIAL IN-MIGRATION AND RURAL DEVELOPMENT IN CZECHIA: A CHALLENGE OF INTEGRATING THE LOCAL AND EXTRA-LOCAL IN RURAL PLANNING
}

\author{
Jan Píša ${ }^{1}$ iD - Vladan Hruška ${ }^{2}$ \\ ${ }^{1}$ Faculty of Social and Economic Studies \\ Jan Evangelista Purkyně University \\ Moskevská 54, 40096 Ústí nad Labem: Czech Republic \\ e-mail: Jan.Pisa@ujep.cz \\ ${ }^{2}$ Faculty of Science \\ Jan Evangelista Purkyně University \\ České mládeže 8, 40096 Ústí nad Labem: Czech Republic \\ e-mail: Vladan.Hruska@ujep.cz
}

\begin{abstract}
Despite the decreasing importance of farming for rural economies, diversification of farming activities is still perceived by the EU as one of the sources of new jobs in rural areas. However, as authors argue, there are more efficient ways for new job generation associated with entrepreneurial rural in-migration. Such migration movement brings new entrepreneurial skills, knowledge, and creativity to rural areas. By presenting the results of our interview survey with urban newcomers to peripheral rural areas of Czechia, we would like to draw attention to this alternative and under-researched way of rural development, especially in the Central and Eastern Europe. This article analyses the contribution of entrepreneurial in-migrants to local economies and examines new ways for better incorporation of rural entrepreneurial in-migration into rural development planning.
\end{abstract}

\section{Key words}

Entrepreneurship $\bullet$ in-migration $\bullet$ rural space $\cdot$ rural planning $\bullet$ Czechia

\section{Introduction}

Agriculture is an inseparable part of rural identity, and as an economic activity, it uses extensive part of rural space. However, its importance for rural employment and national
GDP of developed countries is negligible (Atterton et al. 2012). Despite this fact, agriculture has been the central element of rural development polices, especially within the EU Common Agricultural Policy, which has been criticised by the scientific community 
(e.g., Gray 2000; Rowley 2003; Pělucha \& Květoň 2017), at least since the publication of the Cork Declaration in 1996 (European Commission - AEIDL 1996). Lapping (2006: 118) speaks about 'incredible inertia and lack of imagination' of key actors formulating rural development policies.

Within the currently dominating approach to European rural development - the so-called new paradigm of rural development (Woods 2011) - the potential for rural development is derived from the ability of local stakeholders to valorise local resources predominantly through economic activities of farming, crafts, and tourism. However, it is disputable whether the commodification of strictly local resources is sufficient to cover the employment needs of local populations. Moreover, valorisation of local resources is difficult to achieve if key actors do not dispone with sufficient human, social, and financial capital. Such actors are especially missing in peripheral rural areas which struggle with the outflow of well-educated and experienced rural inhabitants into urban areas and following erosion of local entrepreneurial milieu.

On the other hand, in-migration of urban residents to rural areas who moved to peripheral localities with expectation to improve life quality can be perceived as an important opportunity for renewal of local economies. This kind of migration, labelled in scientific literature as counterurbanization, in quantitative terms partly compensates for the gradual outflow of people from remote rural areas (as it was proven even in the case of rural localities located out of the metropolitan regions of Czechia by Ouředníček et al. 2013) and simultaneously enables transfer of entrepreneurial skills, knowledge, and creativity (Atterton et al. 2012), as well as human, social, and financial capital (Gkartzios \& Scott 2014) from urban to rural areas. Many studies, mainly from the Western developed countries, have proven the positive influence of urban in-migrants on rural economic development (i. e., North \& Smallbone 2006; Kalantaridis 2010; Bosworth \& Atterton 2012; Atterton et al. 2012;
Herslund 2012; Gkartzios \& Scott 2014). Driven by in-migration, such rural entrepreneurs generate job opportunities, promote innovation and help to develop and maintain communities (Newbery et al. 2017). The EU-wide study even claims:

"We argue economic development in rural peripheral areas is closely associated with the entrepreneurial talent of the local population. (...) At the same time, in other rural regions, inmigration appears to be a source of entrepreneurial capacity. Therefore, we advance the idea that rural development policies should centre on the enhancement of the entrepreneurial human capital in the countryside." (European Commission 2003: 15).

However, in Czech rural studies, the entrepreneurial rural in-migration is analysed only very rarely or indirectly and is rather hidden under the label of amenity migration or counterurbanization in general (Bartoš et al. 2011; Novotná 2013; Šimon 2014; Šimon \& Bernard 2016). Ouředníček et al. (2013) argue that the migration balance in recent years has been positive for small rural municipalities out of Czech metropolitan areas, although local impacts as well as the intensity of in-migration to remote rural areas are unevenly distributed throughout the rural space (Ouředníček et al. 2011). Social aspects and motivations to counterurbanization were analysed in several Czech studies (e. g. Šimon 2014; Bernard 2006; Píša 2019), however contribution of this process to local economies was neglected. Similarly, within the Czech rural planning discourse, this opportunity has not been recognised at all yet.

From this point of view, this paper aspires, first, to increase the awareness of the contribution of entrepreneurial in-migration to rural economic development among scientific and planning community of the post-socialist countries. Second, it draws attention to the incompatible configuration of rural development policies which are not able to grasp the issue of this specific aspect of rural inmigration and use it for the rejuvenation of rural areas. In doing this, we develop the ideas of Gkartzios and Scott (2014) who 
stress the importance of rural in-migration for rural development and the necessity of its integration into rural development policies. To achieve the goals of this paper, we structured it as follows. In the first part, we discuss the issue of entrepreneurial rural in-migration based on the literature review mostly from the Western developed countries. Next, rural development approaches are discussed and applied to the Czech rural development policies. In the third part, the contribution of Czech rural newcomers to local economic development is demonstrated based on the interview survey conducted with 12 inmigrant households from peripheral rural areas of North Bohemia in Czechia. Finally, we discuss possible economic contributions of entrepreneurial in-migrants to rural development and introduce implications for rural planners.

\section{Rural entrepreneurial in-migration}

Poor economic performance of peripheral rural areas is a result and consequence of the lack of jobs, presence of economic activities with low value added, limited capacity of human capital (qualified labour) (Gosnell \& Abrams 2009), and low level of entrepreneurship (Płaziak \& Rachwał 2014). From this point of view, in-migration of urban inhabitants usually well-endowed with entrepreneurial skills, knowledge, and creativity (Atterton et al. 2012) or human, social, and financial capital (Gkartzios \& Scott 2014) might be a good opportunity for rejuvenation of rural economies. Although the inflow of entrepreneurial in-migrants might be negligible in some rural localities, their social and economic contribution may be enormous in relation to the small size of local markets and communities (Hugo \& Morén-Alegret 2008).

The motivation for relocation from urban to rural areas always represents a mix of push and pull factors - a combination of negatively perceived urban features and positive (sometimes even idyllic) rural images. Entrepreneurial in-migration is very tightly related to the quality of natural resources (low/ high amenity) of rural destinations (Halliday \& Coombes 1995). However, from this point of view, usually the main motivation of newcomers is not a concrete entrepreneurial activity but primarily the change of lifestyle. Therefore, it is rather the ambition for meeting the needs of in-migrants for living in quiet, nature-close environment which has the main decisive power. Thus, own economic activity in a given rural area is not the main goal of newcomers, their entrepreneurial activity is rather a necessity to satisfy their basic needs. Hence, generated socio-economic and development impulses are rather a by-product of their presence in a rural community (Akgün et al. 2011; Carson et al. 2017).

Good preconditions for entrepreneurial in-migration can be found both in high and less attractive environment (e.g., in the case of Britain, Cornwall, Devon, and East Cumbria (North \& Smallbone 2006) or North East of England (Atterton \& Affleck 2009)). According to Carson et al. (2017), even lowamenity localities have very good chances to attract entrepreneurial in-migrants. Many in-migrants usually choose a lowamenity rural locality not only due to lower price of real estate but also due to their need for a quiet environment which cannot be expected in renowned tourist destinations. New entrepreneurial activities developed by local people then often focus on tourism with a non-mass character in order to keep the rural idyll of entrepreneurial newcomers (Carson et al. 2017).

Current restructuring of rural economies is accompanied by an increasing rate of teleworking in rural areas (together with growing self-employment and part-time contracting). As a result, rural newcomers transform and diversify local economies as their entrepreneurial activities differ from those of autochthonous population. From this point of view, the inflow of in-migrants can lead to the creation of 'new rural economies' (e.g. cluster of ICT businesses in Cornwall and Devon (North \& Smallbone 2006)). These new economies are constructed by urban-rural 
shift of knowledge-intensive and high valueadded economic activities which concentrate in rural localities with corresponding infrastructures (cellnet telephone coverage, internet connection of corresponding bandwidth capacity) and attractive environment. Just such localities have the best potential for becoming popular destinations of rural in-migrants (Atterton et al. 2012).

Whereas the firms of local people rather focus on local community, newcomers' entrepreneurial activities are oriented to much diverse groups of clients. This could be explained by sometimes relatively difficult integration of newcomers into the hosting rural community and different character of target groups they focus on (Smallbone 2009). Markets of rural in-migrants' enterprises usually extend beyond the local community and very often focus on urban consumers. In doing that, rural newcomers use social capital they had established during their life in urban areas (Stockdale 2006). Also, Light et al. (2004) stress the importance of in-migrants' networks of contacts. Thanks to these extra-local networks, new jobs for local people or other newcomers can be generated.

New firms of entrepreneurial in-migrants are not as productive as the firms of local people as regards the capital and new jobs creation because they rather focus on less labour-intensive services in comparison with local people who tend to be active in agriculture. Very often, the character of new economic activities is different from that which the in-migrant practised during his/her urban life. Thus, a new rural economic activity is a way to follow the desire for a new life and cutting-off from the previous urban life. In circumstances like these, such entrepreneurs may not have the necessary skills and experience. But again, he/she can exploit other relevant knowledge and social capital gained in urban areas (Benson \& O'Reilly 2009). The selection of a particular economic activity may be predetermined also by parameters of the purchased rural property in case it follows the property previous use (very often in case of former restaurants and hotels) (Carson et al. 2017).

\section{Rural development approaches and policies with focus on Czechia}

Generally, three theoretical approaches to rural development in developed countries are recognised by rural scholars (van der Ploeg et al. 2000; Terluin 2003; Ray 2006; Woods 2011; Gkartzios \& Scott 2014): exogenous (or modernization paradigm by Woods 2011), endogenous (or new rural development paradigm by van der Ploeg et al. 2000; Woods 2011) and neo-endogenous rural development (see Tab. 1).

Exogenous development is based on topdown interventions. National governments promoted investment in the transport infrastructure, agriculture, or manufacturing in urban centres where the branch-plant economy developed which should have provided jobs also for rural people (for more detailed overview, see Woods 2011; Bosworth \& Atterton 2012; Gkartzios \& Scott 2014). Such development policies based on attracting of both domestic and foreign investment created new jobs in peripheral regions, however, they were very expensive. (Bosworth \& Atterton 2012). Farming was perceived as the key rural economic activity and its low productivity as the main rural development problem (Woods 2011; Gkartzios \& Scott 2014).

Since the 1990s, the new rural development paradigm has been penetrating rural policy discourse in the developed countries. Its basic principles were summarised by Woods (2011) as: endogenous development - valorisation of local resources by local people and initiatives (van der Ploeg et al. 2000), bottom-up model of rural development policies (giving space and voice to local people, initiatives, and firms) and integrated approach (connecting social, economic, and environmental spheres of rural development and integrating other economic activities besides agriculture).

Ray (2006) criticises the new rural development paradigm and suggests the so-called 
neo-endogenous model of rural development which partly redefines the endogenous paradigm. He argues that there is no closed rural locality, and each rural locality is a result of mix of intra- and extra-local processes. Therefore, development approaches should reflect on this factor and stress not only the capability of local people to valorise local resources but also their integration into external networks, social, and political relations. Integration of local people in these networks can significantly facilitate local development process. From this point of view, each rural development endeavour should be "locally rooted, but outward-looking" (Gkartzios \& Scott 2014: 246).

How have been these different rural development approaches integrated into Czech rural development planning? Clearly, the first two approaches still have the dominant position, whereas the neo-endogenous paradigm is practised only limitedly and rather implicitly. Exogenous development approaches dominated the socialist period of rural planning (1948-1989) similarly to other socialist, but also capitalist countries of the Western Europe. In these countries development of rural areas was subordinated to agricultural development (e.g., Pospěch 2014; Kovács et al. 2015). Socialist farms - state (sovkhozes) and collective farms (kolkhozes) -had also significantly transformed rural communities (Hruška 2014) and facilitated establishment of the productivist regime (e.g., Murdoch 1992; Ilbery \& Bowler 1998) which dominated extensive areas of the Czech rural space (Pospěch 2014; Hruška 2014). Technical infrastructure extension and development was based on top-down state interventions and decisions based on a strict hierarchy of settlements (Mulíček \& Malý 2017) which overshadowed the role of local communities.

The end of the communist regime in 1989 and societal, political, institutional, and economic restructuring intensively influenced rural space. The 1990s were characterized by the deepening of crisis in the Czech agriculture. The productivist mode of agriculture installed by the socialist regime had been gradually dismantled, especially in lessfavoured areas for agriculture, and subsequently, agricultural output and employment decreased significantly (Kovács et al. 2015). Pospěch (2014) argues that due to these

Table 1. Comparison of rural development models based on Gkartzios and Scott (2014) (neo-endogenous model with stress on rural housing)

\begin{tabular}{|c|c|c|}
\hline Measure & Key words & $\begin{array}{c}\text { Financial } \\
\text { allocation (\%) }\end{array}$ \\
\hline 1. Competitiveness of agriculture & $\begin{array}{l}\text { life-long learning; innovations in farming and } \\
\text { forestry; modernisation of technologies and produc- } \\
\text { tion facilities }\end{array}$ & 20 \\
\hline $\begin{array}{l}\text { 2. Organisation of the food chain, animal } \\
\text { welfare }\end{array}$ & $\begin{array}{l}\text { capturing of added value; food-processing and } \\
\text { development of new products; vertical and horizon- } \\
\text { tal co-operation within value chains; farm animal } \\
\text { well-being }\end{array}$ & 11 \\
\hline 3. Environmental protection & agri-environmental and biodiversity measures & 59 \\
\hline $\begin{array}{l}\text { 4. Resource efficiency, shift to low-carbon } \\
\text { economy }\end{array}$ & $\begin{array}{l}\text { vertical and horizontal co-operation within the bio- } \\
\text { mass value chain; absorption of } \mathrm{CO}_{2} \text { by new forests } \\
\text { and grasslands }\end{array}$ & 1 \\
\hline 5. Economic development, LEADER & $\begin{array}{l}\text { new farms; diversification and development of non- } \\
\text { agricultural activities; LEADER }\end{array}$ & 7 \\
\hline 6. Technical help & - & 1 \\
\hline 7. Other & - & 1 \\
\hline
\end{tabular}

Source: Based on Gkartzios \& Scott (2014). 
processes rural space lost its dominant agricultural function and label this decade as a period of "discursive no man's land" as there was no symbolic anchoring of rural areas from which their function could have been derived. On the other hand, in the same decade started the rural renewal movement rooted in the endeavour for a rehabilitation of perceived damages caused by the totalitarian regime and especially the forced collectivisation process of the agricultural production. In 1991, the Programme of Village Renewal was formally recognised by the Czechoslovak government (Pospěch 2014) in order to re-create coherent rural communities.

Nevertheless, this representation in the political discourse was weaker than the representation of rural areas as a source of primary commodities. Such kind of representation confirmed the central position of agriculture even in the crisis decade of the 1990s. Central position of farming has been even reinforced since the beginning of the 2000s due to the preparation of the Czech farming for the accession in the EU and its Common Agricultural Policy (CAP). Since then, agriculture has been dominating Czech rural planning instruments. Within the EUfunded Rural Development Programme of the Czech Republic for the period 20142020 (RDP), agriculture and forestry occupy the dominant share of financial allocation (see Tab. 1 or Kovács et al. 2015 for the context of the Central European post-socialist countries). From this point of view, the situation is similar to that of other EU countries, therefore deeply anchored in what Pělucha and Květoň (2017) label as neo-productivist agricultural paradigm which influences rural development approaches throughout the EU.

From this point of view, some dimensions of the exogenous (modernization) approaches to rural development still persist in Czechia (or in the EU) despite official proclamation of rural development with the key role of local communities. We can mention narrow sectoral concentration on farming, dominance of infrastructural and technological measures, and reliance on inward investment without any competition among farms (direct payments). On the other hand, new forms of rural development associated with the new rural development paradigm (endogenous rural development) also appear. Farmers are motivated to diversify their economic activities in order to valorise local resources or increase the value added captured within the locality. Non-farming economic activities are also promoted (albeit with much lower financial allocation - see the measure 5 in Tab. 2), and general accent on sustainability is reflected in agri-environmental measures. Last but not least, the LEADER initiative is the best example of the endogenous development approach. It empowers and enables local communities to participate in rural development (Moseley 2003; Woods 2011).

If we take a closer look at the RDP, it can be observed that only few development measures have extra-local character typical for neo-endogenous approaches to rural development. There is support for information and training events for farmers mediating knowledge of external professionals and building farmers' social capital (Measure 1). Horizontal and vertical cooperation among the participants of short food supply chains and local markets is also promoted, facilitating farmers to better control their profits and value-adding activities in the competition with mostly urban-based retail chains (Measure 2). Local Action Groups (LAGs) can apply grants for organisation of information, training and recreation events; promotion of local products consumption (including branding of local products and services); and investment in local information and tourist centres (Measure 5). Other measures of the RDP have only hardly extra-local character.

\section{Methodology: interviews with Czech entrepreneurial in-migrants}

For our research, we conducted semi-structured interviews with members of 12 households (usually with wage earners; see Tab. 3). 
Table 2: List of measures of the Rural Development Programme of the Czech Republic for the period 2014-2020

\begin{tabular}{|c|c|c|c|}
\hline & Exogenous & Endogenous & Neo-endogenous \\
\hline $\begin{array}{l}\text { Key } \\
\text { principle }\end{array}$ & $\begin{array}{l}\text { Economies of scale and con- } \\
\text { centration. }\end{array}$ & $\begin{array}{l}\text { Sustainable valorisation of lo- } \\
\text { cal resources. }\end{array}$ & $\begin{array}{l}\text { Socio-spatial justice and } \\
\text { balancing local needs while } \\
\text { competing for extralocal } \\
\text { people, resources skills and } \\
\text { capitals. }\end{array}$ \\
\hline Dynamic force & $\begin{array}{l}\text { Urban growth poles. The main } \\
\text { forces of rural development } \\
\text { conceived as emanating from } \\
\text { outside rural areas. }\end{array}$ & Local initiative and enterprise. & $\begin{array}{l}\text { Fostering a new urban rural } \\
\text { and local-global relationship } \\
\text { through inclusive, multi-scalar } \\
\text { and multi-sectoral governance } \\
\text { arrangements. }\end{array}$ \\
\hline $\begin{array}{l}\text { Function of rural } \\
\text { areas }\end{array}$ & $\begin{array}{l}\text { Food and other primary } \\
\text { production for the expanding } \\
\text { urban economy. }\end{array}$ & Diverse service economies. & $\begin{array}{l}\text { Sustaining rural livelihoods, } \\
\text { while maintaining natural } \\
\text { capital. Mosaic of re-emerging } \\
\text { productivist functions and } \\
\text { consumerist uses. }\end{array}$ \\
\hline $\begin{array}{l}\text { Major rural } \\
\text { problems }\end{array}$ & $\begin{array}{l}\text { Low productivity and periphe- } \\
\text { riality. }\end{array}$ & $\begin{array}{l}\text { The limited capacity of areas } \\
\text { and social groups to partici- } \\
\text { pate in economic and develop- } \\
\text { ment activity. }\end{array}$ & $\begin{array}{l}\text { Exclusive countrysides. Neolib- } \\
\text { eral deregulation versus policy } \\
\text { apathy and lack of regulation. } \\
\text { Climate change challenges. }\end{array}$ \\
\hline $\begin{array}{l}\text { Focus of rural } \\
\text { development }\end{array}$ & $\begin{array}{l}\text { Agricultural industrialisation } \\
\text { and specialisation. Encourage- } \\
\text { ment of labour and capital } \\
\text { mobility. }\end{array}$ & $\begin{array}{l}\text { Capacity building (skills, } \\
\text { institutions, infrastructure). } \\
\text { Overcoming social exclusion. }\end{array}$ & $\begin{array}{l}\text { Place-making and com- } \\
\text { munity wellbeing. }\end{array}$ \\
\hline
\end{tabular}

Source: Ministry of Agriculture of the Czech Republic, 2018.

This method allowed the interview partners to mention relevant and important facts for them while the interviewer could (based on a pre-compiled set of topics) verify that these topics had already been discussed. For semi-structured interviews, households of entrepreneurial in-migrants were selected according to the following criteria:

- permanent residence in rural (rather peripheral) space;

- rural in-migration driven by desire to improve the quality of life or to start or develop his/her business;

- daily activities of the household taking place mostly in rural space - household members did not commute to urban areas frequently due to their work, shopping activities, etc.

In order to find relevant interview partners, we contacted representatives of rural municipalities and LAGs and other local actors (NGOs) within the region of North
Bohemia in Czechia and asked whether they could identify a household which meets the selected criteria. We also contacted entrepreneurs in the selected region using online databases of local businesses, databases of producers with regional labelling, and online maps which provide basic information about local businesses.

Semi-structured interviews were conducted during February, March, and April 2017 in the area of North Bohemia in Czechia (Fig. 1). The region of North Czechia was selected due to its higher number of rural in-migrants from urban centres such as Prague, Ústí nad Labem, and Liberec. Very often, these in-migrants have relocated in their new destinations due to attractive landscapes of Protected Landscape Areas (PLA Labské pískovce, PLA Kokořínsko - Máchův kraj, PLA České středohoří Mountains), National Park České Švýcarsko or other rural regions. Almost all interviews 
Table 3: Profile of interview partners

\begin{tabular}{|c|c|c|c|c|c|c|c|}
\hline \multirow{2}{*}{ 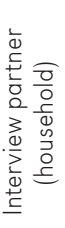 } & \multirow[b]{2}{*}{$\begin{array}{l}\frac{1}{d} \\
\frac{1}{0} \\
0 \\
0\end{array}$} & \multirow[b]{2}{*}{ 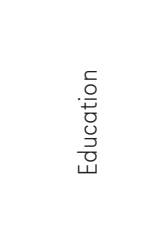 } & \multirow[b]{2}{*}{$\begin{array}{l}. \frac{5}{0} \\
. \frac{0}{0} \\
\frac{4}{0} \\
0 \\
0 \\
\frac{0}{0}\end{array}$} & \multicolumn{2}{|c|}{ Migration } & \multirow[b]{2}{*}{ 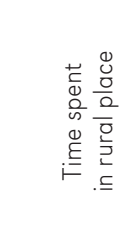 } & \multirow{2}{*}{ 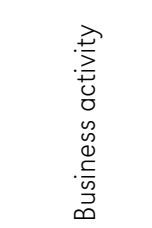 } \\
\hline & & & & ह & 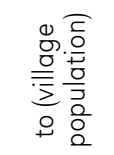 & & \\
\hline 1 & $\begin{array}{l}F \\
M\end{array}$ & $\begin{array}{l}\text { University } \\
\text { High school }\end{array}$ & $\begin{array}{l}\text { Prague } \\
\text { Prague }\end{array}$ & Prague & $100-200$ & 5 years & $\begin{array}{l}\text { Café, } \\
\text { restaurant }\end{array}$ \\
\hline 2 & $\begin{array}{l}M \\
F\end{array}$ & $\begin{array}{l}\text { University } \\
\text { University }\end{array}$ & $\begin{array}{l}\text { Small town } \\
(5,000) \\
\text { Prague }\end{array}$ & Prague & $100-200$ & 2 years & $\begin{array}{l}\text { Brewery, pub, } \\
\text { tours }\end{array}$ \\
\hline 3 & $\begin{array}{c}M \\
F\end{array}$ & $\begin{array}{l}\text { High school } \\
\text { High school }\end{array}$ & $\begin{array}{l}\text { Most } \\
\text { Town }(25,000)\end{array}$ & Most & $100-200$ & 12 years & Farm, tours \\
\hline 4 & $\begin{array}{l}\mathrm{F} \\
\mathrm{M}\end{array}$ & $\begin{array}{l}\text { University } \\
\text { University }\end{array}$ & $\begin{array}{l}\text { Pardubice } \\
\text { Most }\end{array}$ & $\begin{array}{l}\text { Ústí nad } \\
\text { Labem }\end{array}$ & $200-300$ & 2 years & $\begin{array}{l}\text { Stone } \\
\text { decorations }\end{array}$ \\
\hline 5 & $\begin{array}{l}\mathrm{F} \\
\mathrm{M}\end{array}$ & $\begin{array}{l}\text { High school } \\
\text { High school }\end{array}$ & $\begin{array}{l}\text { Chomutov } \\
\text { Chomutov }\end{array}$ & Chomutov & $50-100$ & 20 years & $\begin{array}{l}\text { Agriculture, } \\
\text { guesthouse }\end{array}$ \\
\hline 6 & $\begin{array}{l}\mathrm{F} \\
\mathrm{M}\end{array}$ & $\begin{array}{l}\text { High school } \\
\text { University }\end{array}$ & $\begin{array}{l}\text { Prague } \\
\text { Prague }\end{array}$ & Prague & $50-100$ & 9 years & $\begin{array}{l}\text { Guesthouse, } \\
\text { café }\end{array}$ \\
\hline 7 & $\begin{array}{l}\mathrm{F} \\
\mathrm{M}\end{array}$ & $\begin{array}{l}\text { High school } \\
\text { High school }\end{array}$ & $\begin{array}{l}\text { Prague } \\
\text { Prague }\end{array}$ & Prague & to 50 & 15 years & Farm, dairy \\
\hline 8 & $\begin{array}{l}M \\
F\end{array}$ & $\begin{array}{l}\text { High school } \\
\text { High school }\end{array}$ & $\begin{array}{l}\text { Small village } \\
\text { Prague }\end{array}$ & Prague & to 50 & 7 years & Beekeeping \\
\hline 9 & $\begin{array}{l}M \\
F\end{array}$ & $\begin{array}{l}\text { High school } \\
\text { University }\end{array}$ & $\begin{array}{l}\text { Prague } \\
\text { Prague }\end{array}$ & Prague & $600-700$ & 16 years & Guesthouse \\
\hline 10 & $\mathrm{~F}$ & University & Liberec & Liberec & to 50 & 5 years & Bakery \\
\hline 11 & $\begin{array}{l}\mathrm{F} \\
\mathrm{M}\end{array}$ & $\begin{array}{l}\text { High school } \\
\text { High school }\end{array}$ & $\begin{array}{l}\text { Děčín } \\
\text { Small town } \\
(3,500)\end{array}$ & $\begin{array}{l}\text { Small town } \\
(3,500)\end{array}$ & $300-400$ & 30 years & $\begin{array}{l}\text { Soap factory, } \\
\text { hotel }\end{array}$ \\
\hline 12 & $\begin{array}{l}\mathrm{F} \\
\mathrm{M}\end{array}$ & $\begin{array}{l}\text { High school } \\
\text { High school }\end{array}$ & $\begin{array}{l}\text { Ústí nad } \\
\text { Labem } \\
\text { Ústí nad } \\
\text { Labem }\end{array}$ & $\begin{array}{l}\text { Ústí nad } \\
\text { Labem }\end{array}$ & $100-200$ & 8 years & $\begin{array}{l}\text { Web design, } \\
\text { joinery }\end{array}$ \\
\hline
\end{tabular}

(11) were conducted at interview partners' homes or their production facilities (Fig. 1), one meeting was arranged at the farmer's market in Prague.

Interviews focused on general aspects of rural entrepreneurial activity, particularly with regard to the in-migrant's impact on local economies. More specific topics arose during the interviews (described in the following section). Based on the respondent's agreement, recording device was used or notes were made. At the beginning of the interview, the general topic was sketched and space for interviewee's narration was 


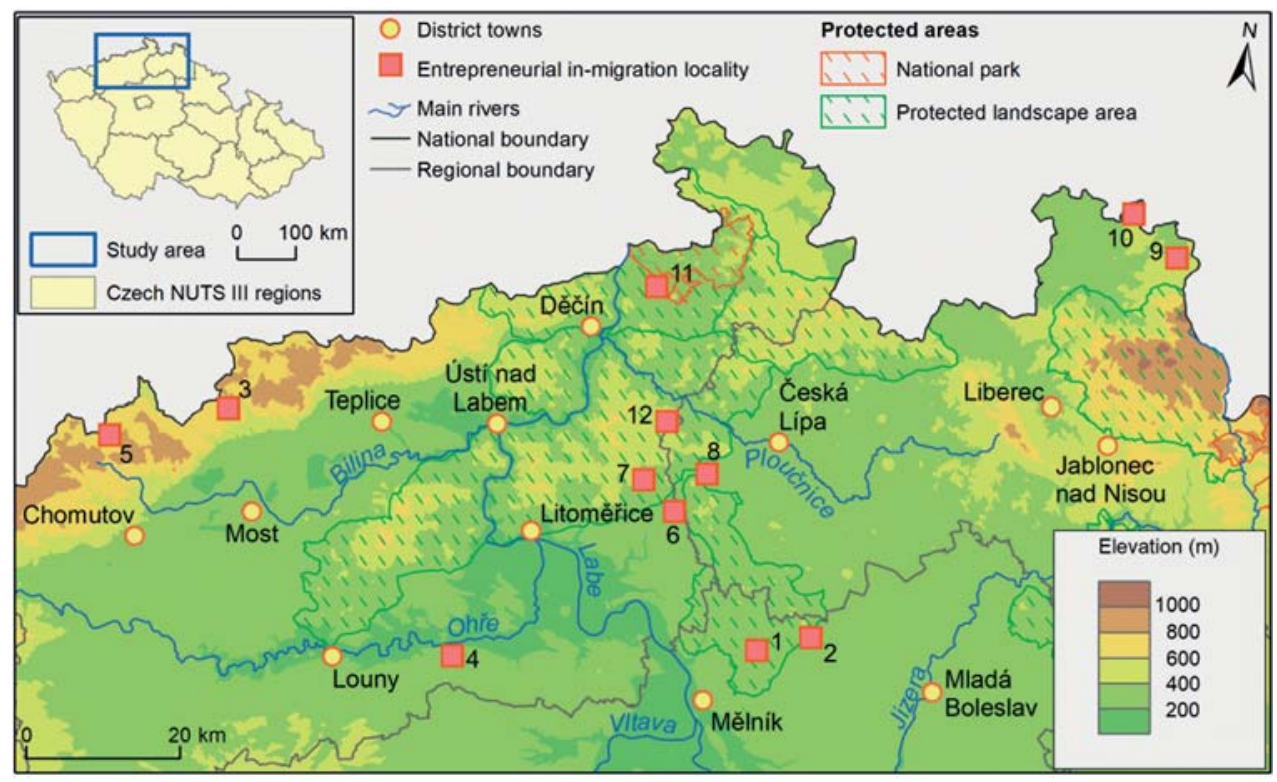

Figure 1. Locations of the interview partners (entrepreneurial in-migration locality) in the region of North Bohemia in Czechia

Source: ArcČR® 500, version 3.3 database.

given. If interviewer considered some statements to be useful, the partner was asked for a deeper explanation of a particular topic or answer to additional questions. For coding the interviews, thematic analysis was used (Hendl 2016), whereby we focused on codes indicating connections to the researched topic.

Some methodological obstacles can be identified. Given the way of searching for the interview partners, the selection of interview partners cannot be considered as representative. Second, the study area seems to be quite heterogeneous in terms of the landscape attractiveness, social composition etc. which could subsequently influenced the structure of entrepreneurial inmigrants and their potential impact on rural localities. Nevertheless, we do not consider this as a problem, because the aim of our research is not the clarification of the spatial distribution of the entrepreneurial in-migration but rather identification of specific economic impacts of this phenomenon at the local scale.

\section{Entrepreneurship of Czech rural newcomers: motivations, contributions to local economies and conflicts}

Based on the semi-structured interviews, first, we focused on motivations of entrepreneurial in-migrants for relocation from urban to rural areas as this is a necessary precondition of their economic engagement in a given rural locality. Second, we examined their diverse contributions to local economy. All these topics are demonstrated in following paragraphs. However, these aspects are often intermingled and integrated with other ways of benefits for rural economies as it was impossible and on the other hand not necessary to separate them.

As regards the motivation for migration to rural space, it seems that most of the interviewed rural newcomers looked for a change, a new job within which they could act more independently and find self-fulfilment. Interview partner 2 (IP 2) stated: 
"I no longer wanted to work for other people. I didn't want to develop something for them and give them my know-how anymore. Because it's not about the drawing [of construction plans - authors' note] - you give them the idea! And actually, they do not want to pay for it. (...) So I said stop. I will devote my energy to my things. My things are now able to feed me better than those things."

Oftentimes, the motivation to leave the city stemmed from the romanticized perception of rural space as a space where 'dreams come true' - from this point view, variations of rural idyll could be found in the agency and perceptions of Czech rural newcomers. Urban areas were defined by newcomers as space of hectic life, and strong urban-rural dichotomy might be observed in the perception of rural in-migrants:

"Well, when we moved to the countryside seven years ago, my husband bought about five hives. Only for our needs. One year later we had about 16 hives. My husband worked in the bank at that time. He did not really enjoy the work in the office. He is such a natural person. So, he didn't feel good in the office. He did well his job, but it wasn't that what he was looking for. So, the next year he decided to do the beekeeping professionally. So later, from those fifteen hives at the beginning we jumped to 75 and that was a big change." (IP 8).

As it is visible in the statements above, entrepreneurial in-migrants were very often unsatisfied with their sub-ordinated position in their company. From this point of view, rural space is perceived as a space of freedom and space which enable development of their own activities. Interview partner 7 stated:

"We didn't want to work in a transnational corporation, we knew it for sure. But on the other hand we are not such mad "organic" people. My husband wanted to rear domestic animals. I would say that it was really such a romantic idea. Something like as they colonised the American frontier. We thought that we would have started something from the beginning and we could have made it according to our ideas. But it's not like this. It has rather created us."

Similarly, interview partner 5 explains his/ her motivations for moving to countryside:

"I studied agricultural school. So I have a very close relationship to agriculture. But I also used to work in an office where we did it stuff. So, in the city it is something totally different. On the contrary, in the village I got back to that what I originally wanted to do and what I like most. But in that city, I did something different. So, I didn't want to be in that city anymore."

Entrepreneurial activity has a central or partial role in the perception of rural life of several in-migrants. However, only one of 12 interview partners had a clear idea of a particular type of activity before moving in the hosting locality (IP 1). The business plan of other migrants is a result of the character of their new residence (e.g. IP 2 - brewery brownfield, IP 6 - farmstead), or general wishes and ideas about satisfying activities (animal breeding/agriculture - IP 3, 5, 7; baking - IP 10, beekeeping - IP 8, art activity - IP 4) and of course the need to earn money for living. Despite these statements, the motivation for having a meaningful job after moving to the rural cannot be overestimated. Reasons for migration stem rather from the perceived urban-rural dichotomy and are largely related to the individual's previous experience with the rural. It is evident that in most cases migrants do not wish to operate a specific business activity, but rather a job that is more meaningful for them than the previous urban one. Therefore, the rural business plan is rather part of a wider effort to get rid of city ties and reach personal satisfaction both veiled by individual conceptions of rural idyll (see more in Píša 2019). Furthermore, it is important to note (in accordance to Stockdale 2014) that there are often other - more individual factors related to important life events (divorces, death in the family, heritage etc.) contributing to urban-rural migration.

In the following paragraphs we would like to focus on diverse contributions of entrepreneurial in-migrants to local economies. 
Entrepreneurial in-migrants showed ability to generate new jobs. Twelve examined households created totally 64 jobs (for their detailed analysis see Tab. 4).
"It's difficult to find some workers now. Really difficult. Because there are so many job-offers and we can't pay much. There are people [on the farm - authors' note] who have

Table 4. Jobs generated by interviewed entrepreneurial in-migrants

\begin{tabular}{|c|c|c|c|c|c|c|c|}
\hline \multirow{2}{*}{$\begin{array}{c}\text { Household } \\
\text { number }\end{array}$} & \multirow{6}{|c|}{ New jobs } \\
\cline { 2 - 8 } & total & \multicolumn{3}{|c|}{ self-employment } & \multicolumn{3}{c|}{ other } \\
\cline { 2 - 8 } & & $\begin{array}{c}\text { full-time } \\
\text { jobs }\end{array}$ & $\begin{array}{c}\text { part-time } \\
\text { jobs }\end{array}$ & $\begin{array}{c}\text { seasonal } \\
\text { jobs }\end{array}$ & $\begin{array}{c}\text { full-time } \\
\text { jobs }\end{array}$ & $\begin{array}{c}\text { part-time } \\
\text { jobs }\end{array}$ & $\begin{array}{c}\text { seasonal } \\
\text { jobs }\end{array}$ \\
\hline 1 & 9 & 2 & 0 & 1 & 0 & 0 & 6 \\
2 & 11 & 2 & 0 & 0 & 2 & 1 & 6 \\
3 & 2 & 1 & 1 & 0 & 0 & 0 & 0 \\
4 & 2 & 0 & 2 & 0 & 0 & 0 & 0 \\
5 & 7 & 2 & 0 & 0 & 0 & 2 & 3 \\
6 & 5 & 1 & 0 & 0 & 0 & 1 & 3 \\
7 & 10 & 2 & 0 & 0 & 6 & 0 & 2 \\
8 & 2 & 2 & 0 & 0 & 0 & 0 & 0 \\
9 & 4 & 0 & 2 & 0 & 0 & 1 & 1 \\
10 & 3 & 1 & 0 & 0 & 1 & 0 & 1 \\
11 & 6 & 2 & 0 & 0 & 3 & 1 & 0 \\
12 & 3 & 2 & 0 & 0 & 1 & 0 & 0 \\
\hline Total & 64 & 17 & 5 & 1 & 13 & 6 & 22 \\
\hline
\end{tabular}

From this point of view, the impact of the surveyed entrepreneurial migrants on the local labour market is relatively strong although the quality of these jobs is questionable. A high proportion of them are parttime or seasonal jobs (for students, retired). Some activities are considered by potential employees (according to some interview partners) to be inferior (often also poorly paid). This is probably one of the reasons (apart from currently very low unemployment rate in Czechia) why newcomers' businesses experience shortage in workers. This problem is more acute in case of more complex and better paid positions which require skilled workforce. Very often people living in urban centres are hired for these positions; therefore, this situation leads to urban to rural commuting paradox. some personal reasons for that. They don't want to commute for long distances, they haven't a chance to find a better job, or they don't want to make a job in the corporation just like me. Or they want to work outside and so on.' (IP 7)

'We have a shop and one employee. He commutes from Ústí nad Labem [the regional capital - authors' note]. We didn't find any worker here in the village. The skilful people already have their job and we don't want the 'left-handed'. But it is always like this." (IP 12).

Newcomers' businesses promote networking with other local businesses and economic multiplication, or more intensive local circuits of value added. The larger is the firm (in comparison to the village population), the higher is the multiplication effect for the 
local economic/entrepreneurial milieu. The case of small local brewery (IP 2) illustrates the situation very well. The reason is it's relatively large size and wide range of services it offers which increases the capacity and attractiveness of the village from the perspective of tourism. The brewery also fits well into the local mosaic of already existing small businesses and contributes to the emergence of new enterprises:

"Suddenly some young boys appeared. Somewhere from those villages by the town Mělnik. Because we don't have a restaurant here in the brewery, they started to cook. (...) It doesn't matter to me, because I don't really cook here. Moreover, they started to serve our beer. (...) And the local authority is also glad to have a tenant there [they are running their restaurant in municipal premises - authors' note]. (...) Our neighbours moved from the upper floor to the ground floor and upstairs they renovated three rooms and made a guesthouse there. And it is sold out for the whole season. (...) Even the castle is prospering now, not only because of the brewery. Because there is a guesthouse in the castle. (...) So, the castle is doing well because it proved to be very attractive for the guests and for wedding guests. So they come here to drink beer and for excursions, then they go back to the castle. There is a synergistic effect, definitely." (IP 2)

Multiplication effect, economic localization and the synergy between newcomers' enterprises and other local firms and people are, however, partly limited due to target groups on new enterprises. They are rather focused on extra-local, usually urban-based customers (e. g. firms of interview partners in tourism, farmers sold food via farmer's markets, luxury goods is sold on e-shops). Maintaining financial capital within a rural location therefore depends primarily on the decision of the migrants themselves. Such decision might be adjusted or transformed by the size of local markets or by an existence of other competitive or supporting local services.

New economic activities of rural inmigrants create or transform existing images of the hosting municipalities. Again, the more visible is the economic activity, the larger is the impact on local image:

"Our project was accepted, of course, positively because it helped our village very much. And it was in such a bad state [the brewery building - authors' note] (...) It looked like a total ruin that really fell apart. (...) Today, there is not just a yellow rectangel [special marking in tourist maps indicating level of tourist attractivity - authors' note] in the current volume of the tourist map-the rectangle is already filled in with yellow. There are not many points like this in this region. (...) So it is developing. It certainly develops well." (IP 2).

Due to extra-local orientation of some new economic activities they are able to attract extra-local people which bring financial capital in local economies. However, due to this orientation, some economic activities even appear as cut-off from local communities - as such, they lead to exclusion of local people from the participation on new economic activities:

"Totally different [from local people authors' note] and interesting people come here due to our brewery. We don't need to engage in local community." (IP 2).

Other interview partner (IP 6) opened a café and would like to focus rather on urban visitors than local people (see the quotation few paragraphs below). Such orientation might be the reason for rather contradictory perception of migrant activities from the perspective of long-term dwellers. In-migrants' businesses are often initially understood as an exotic element that is not compatible with local constructions of rurality. Some inmigrants also feel the envy (IP 2, IP 7, IP 6) from the local community members.

"The newcomers try to run a business, earn money, do something what is visible. But the old residents don't want any changes. It brings conflicts. People are reported to the police or local government that someone's horse or sheep ran and eat the neighbour's garden. The cops must deal with these things." (IP 5) 
Some interview partners note the negative attitude of local government (especially the mayor) to their entrepreneurship. Some of them don't understand the lack of support for their activity (IP 1, IP 4, IP 5) and one of them finds the attitudes of political elites as clearly obstructive (IP 2).

"We have encountered a number of very illogical reactions [for the business activity - authors' note], even by the mayor and local government. (...) Everything bothers them. That people come here and park here, that music plays here. Everything. So, I said to myself that I would just have to candidate to the local government. At least to be there and just deny some retard ideas and negate them." (IP 2).

Entrepreneurial in-migrants have identified themselves very quickly with their new locality and became involved in local community renewal:

"So we will secure our living by doing this [stone decorations - authors' note] as long as it is possible. I was a teacher, and now I have extended my parental leave by one year. And then I'd like to work in this firm... to expand its activities for example by painting. I would like to make art studio in the attic and do some courses for the public in order to revive it here [in this village - authors' note] a bit. So now we have some kind of relationship [to this village - authors' note]. Or at least I personally have a relationship to our neighbourhood, to the nature. So I would like to practice various kind of educational activities focused on environmental education or similar things." (IP 4)

Their engagement is very often part of their business strategies and launches commodification of local resources including nature:

"Because when we created this [hotel - authors' note], we used to say that people or kids need to have some fun here too. So we built a nature trail. I have to say that even local people, who do not like me very much, appreciated the fact that we did something amazing. (...) So the whole public can benefit from it but primarily we did it for our clients, I could say." (IP 5).
Entrepreneurial attitudes of rural newcomers also facilitated diversification of rural economies based on exploitation of local resources. New farmers (IP 3) offer farm excursion and wood-processing workshop, and brewery owners (IP 2) offer beer as a new local product in the given locality and organise guided tours in their brewery. In summer season, hotel owners (IP 5) offer cosmetic services such as massage and pedicure. New economic activities also fill gaps in local economies and serve local consumers with specific consumer needs:

"I never wanted a pub. I wanted a café. I am here for mothers with children, for active urban people who are going for a trip. (...) But I do not want to have 'tramps' [special subculture in Czechia - people who like hiking and sleeping in the nature - authors' note] here, who just get drunk. They should sit there [in the pub across the street - authors' note]." (IP 6).

Similarly, IP 7 stated:

"But local people don't buy our farm products very often. I can notice it mostly when we have on-farm sale during the weekends when mostly second-home owners or tourists are buying our products. But locals? ... Some of them are coming because they have allergic children, but this is a specific case."

Previous statement indicates the necessity of rural entrepreneurs to connect to extralocal networks in order to ensure demand for their products/services. Regarding this, farming newcomers integrate their business channels in alternative food networks:

"We have on-farm sale. We already have our regular customers who are coming. And around us, I will bring them my honey in the radius of thirty kilometres on demand. Well, we sell also in Prague on two big farmers' markets and in Roudnice nad Labem. Actually, there is no other choice. These are the bigger cities where we have our customers. I can't go to a small town. Maybe we can sell also in Česká Lípa which is located close to our farm. We were couple times there on the market too and surprisingly we sold well. So, it's diverse. Maybe we will sell 
in Liberec soon. Farmers' market starts there now." (IP 8).

\section{Discussion and conclusions}

Our research confirmed rather positive contribution of entrepreneurial in-migrants for local economies. Their benefits for rural space apart from their social and environmental impact (which we don't discuss within this paper) can be expressed by their contribution to:

- job creation (albeit the attractiveness of these jobs for local people is rather low),

- development of local circuits of value added,

- image-building of a given rural locality and induced capital accumulation,

- commodification of local assets,

- development of new by-products and services,

- diversification of rural economies.

On the other hand, there are some problematic points related to the development of newcomers' businesses. Predominantly, it was the segregation of new business activities from the original local community partly as a result of the necessary extension of business activities to larger/more wealthy urban markets/dwellers or individual values and attitudes which are reflected in the orientation of new business activities. As a consequence, entrepreneurial in-migrants felt some kind of conflict between them and local community.

Many studies (for their overview see e.g. Mayer et al. 2016) stress the necessity of rural businesses to develop rural-urban linkages in order to ensure their competitiveness and approach to larger markets. Our study also confirms these findings. Urban focus of our model enterprises is usually given by weak demand on the local market. However, entrepreneurial in-migrants usually didn't perceive this as a problem and from the start-up phase they focused on the extralocal urban clientele.

Anyway, entrepreneurial in-migrants play the key part in rural development processes and as such, corresponding position in rural development policies and strategies should be reserved for them. Rural scholars already recognised the shortcomings of exogenous and endogenous approaches to rural development and made way for more open and dynamic neo-endogenous approach to rural development. However, the paradigmatic shift between rural development approaches towards larger support of entrepreneurial in-migration has not been much reflected in present rural development policies and strategies on the Czech or European level yet. These policies continue to prefer exogenous or endogenous approaches which are not able to grasp extra-local flows, or if yes in case of the exogenous approach, they support over-dimensional rural dependence on urban areas or central decisions.

Therefore, it is necessary to open rural planning approaches to external flows and driving forces and recognise the benefits of the neo-endogenous approach. Some of these aspects are already incorporated in the LEADER initiative confirming its importance for rural development. LEADER is not only appreciated due to its effectiveness to integrate local people into local decision making but also due to its potential to formulate sensible policies for stimulation of local entrepreneurship (North \& Smallbone 2006). Regarding this, more space should be given to these initiatives and most importantly, one of the main principles of LEADER approach - integrated territorial development - should be emphasised.

Integration from this point of view should mean not only sectoral integration but also territorial one. It should mean the integration of urban and rural places and extra-local and urban-reaching thinking. As it was discussed above, new rural enterprises do employ rural-urban linkages and in fact, they are highly dependent on them as extra-local clientele is crucial for their viability. Therefore, it would be benefitting to use LEADER for such activities as in Czechia LAGs contain both rural and urban settlements albeit inclusion of large regional centres would be more 
benefitting (in Czechia the LAGs may contain only towns with population less than 25,000 ). This gives rural planners a good opportunity to profit from such kind of urban-rural partnership and hereby cross the spatial limitations of individual rural municipalities.

Moreover, multilevel governance and rural planning should better facilitate more equal spatial distribution of human resources and entrepreneurial knowledge (for a detail division of tasks among individual planning levels see Hruška et al. (2015)). Some authors such as North and Smallbone (2006) argue for initiatives supporting in-migration of wellqualified people lacking entrepreneurial skills, especially in rural areas. Therefore new rural development policies should deliver incentives for deconcentration of human, social, financial capital through rural entrepreneurial in-migration and take measures which enable partial disconnection of potential in-migrants from urban areas (Atterton \& Affleck 2009). From this point of view, one of the ways how to attract entrepreneurial talent to rural areas which requires co-operation among different planning scales is to focus on positive presentation of rural areas as a good place for living and doing business e.g. by pointing at the best practice examples of successful firms located in rural areas. Or better targeted policies can be implemented with focus on potential in-migrants who can be both people without any relation to a hosting rural locality or/and people who have family ties to the rural place and left it before due to better employment opportunities in urban areas or even other countries. Return of remigrants

\section{References}

Akgün A.Y.A., Baycan-LeVent T.N., Nijkamp P., Роот J., 2011. Roles of local and newcomer entrepreneurs in rural development: A comparative meta-analytic study. Regional Studies, vol. 45, no. 9, pp. 1207-1223.

Atterton J., Affleck A., 2010. Rural businesses in the North East of England. Retrieved from could be facilitated by a diverse spectre of policies on different levels (e.g. Kovács et al. 2013). European and national authorities may also motivate companies to implement teleworking-friendly policies which may enable many people to live further from their workplaces (in remote rural areas) and later, maybe, develop their own business ideas.

Anyway, configuration of these new rural development policies requiring intersectoral, interterritorial and multiscalar cooperation won't be an easy task.

\section{Acknowledgments}

Jan Píša would like to thank the Internal Grant Agency of the Jan Evangelista Purkyně University in Ústí nad Labem for the financial support (Project Podnikatelská migrace z měst na venkov: její význam pro rozvoj venkovských oblastí a reflexe $v$ plánování venkova/Entrepreneurial urban-to-rural migration: its importance for rural development and its reflection in rural development policies).

Vladan Hruška would like to thank the European Union, European Social Fund and the Ministry of Education, Youth and Sports of the Czech Republic for the financial support of this paper (Project Smart City - Smart Region - Smart Community - CZ.02.1.01/0.0 /0.0/16_025/0007435).

\section{Editors' note:}

Unless otherwise stated, the sources of tables and figures are the authors', on the basis of their own research.

https://www.ncl.ac.uk/media/wwwnclacuk/ centreforruraleconomy/files/NE-rural-business. pdf [2 November 2018].

Atterton J., Bryden J., Johnson T.G., 2012. Rural economic transformation in the UK and US [in:] M. Shucksmith, D.L., Brown, S. Shortall, J., Verguns, M.E., Warner (eds.), Rural transformations and rural policies in the US and UK, London: Routlege, pp. 117-137. 
Bartoš M., Kušová D., TĚšltel J., Novotná M., Kopp J., MaHÁČEK J., Moss L.A.G., Glorioso R.S., 2011. Amenitní migrace do venkovských oblastí České republiky. Kostelec nad Černými lesy: Lesnická práce.

Benson M., O'Reilly K., 2009. Migration and the search for a better way of life: A critical exploration of lifestyle migration. The Sociological Review, vol. 57, no. 4, pp. 547-766.

Bernard J., 2006. Sociální integrace pristěhovalců z velkoměsta na vesnici v České republice a $\vee$ Rakousku. Sociologický časopis / Czech Sociological Review, vol. 42, no. 4, pp. 741-760.

Bosworth G., Atterton J., 2012. Entrepreneurial in-migration and neoendogenous rural development. Rural Sociology, vol. 77, no. 2, pp. 254-279.

Carson D.A., Carson D.B., Eimermann M., 2017. International winter tourism entrepreneurs in northern Sweden: Understanding migration, lifestyle, and business motivations. Scandinavian Journal of Hospitality and Tourism, vol. 17, no. 4, pp. 183-198.

Čermák Z., Novák J., OuŘedníček M., 2011. Saldo migrace / Net migration [in:] M. Ouředníček, J. Temelová, L. Pospíšilová (eds.), Atlas sociálně prostorové diferenciace České republiky. Praha: Nakladatelství Karolinum, pp. 89-90.

European Commission - AEIDL, 1996. The Cork Declaration: Rural Europe - Future Perspectives. European Conference on Rural Development, Cork (Ireland), November 7-9, 1996.

European COMmission, 2003. EU research on social sciences and: The future of Europe's rural periphery, the role of entrepreneurship in responding to employment problems and social marginalization. Brussels: European Commission, http://cordis.europa.eu/docs/publications/1001/100124141-6_en.pdf [2 November 2018].

Gkartzios M., Scott M., 2014. Placing housing in rural development: Exogenous, endogenous and neo-endogenous approaches. Sociologia Ruralis, vol. 54, no. 3, pp. 241-265.

Gosnell H., AbRams J., 2009. Amenity migration: diverse conceptualizations of drivers, socioeconomic dimensions, and emerging challenges. GeoJournal, vol. 76, no. 4., pp. 303-322.

Gray J., 2000. The Common Agricultural Policy and the re-invention of the rural in the European Community. Sociologia Ruralis, vol. 40, no. 1, pp. 30-52.
Halliday J., CoOmbes M., 1995. In search of counterurbanisation: some evidence from Devon on the relationship between patterns of migration and motivation. Journal of Rural Studies, vol. 11, no. 4, pp. 433-446.

HeNDL J., 2005. Kvalitativní výzkum: Základní teorie, metody a aplikace. Praha: Portál.

HeRSLUND L., 2012. The rural creative class: Counterurbanisation and entrepreneurship in the Danish countryside. Sociologia Ruralis, vol. 52, no. 2, pp. 235-255.

HRUŠKA V., 2014. Diferenciace venkovského prostoru na př́kladu Moravskoslezského kraje. [Dissertation thesis], Brno: Masarykova univerzita, Prírodovědecká fakulta.

HruŠKa V., CZAPIEWski K., Kovács Z., 2015. Rural economic development in the post-agricultural era: Policy recommendations. Studia Obszarów Wiejskich, vol. 39, pp. 129-144.

Hugo H., Morén-Alegret R., 2008. International migration to non-metropolitan areas of high income countries: Editorial introduction. Population, Space and Place, vol. 14, no. 6, pp. 473-477.

IlBeRY B., BOWLer I., 1998. From agricultural productivism to post-productivism [in:] B. Ilbery (ed.), The geography of rural change, Essex: Longmann, pp. 57-84.

KALANTARIDIS C., 2010. In-migration, entrepreneurship and rural-urban interdependencies: The case of East Cleveland, North East England. Journal of Rural Studies, vol. 26, no. 4, pp. 418-427.

Kovács Z., Boros L., Hegedús G., Lados G., 2013. Returning people to the homeland: Tools and methods supporting remigrants in a European context [in]: T. Lang (ed.), Return migration in Central Europe: Current trends and an analysis of policies supporting returning migrants, Forum IfL 21, Leipzig: Leibniz-Institut für Länderkunde, pp. 58-94.

Kovács Z., Csachová S., Ferenc M., HrušKa V., KONOPSKI M., 2015. Development policies on rural peripheral areas in Visegrad countries: a comparative policy analysis. Studia Obszarów Wiejskich, vol. 39, pp. 77-102.

LAPPING M., 2006. Rural policy and planning [in:] P. Cloke, T. Marsden, P. Mooney (eds.), Handbook of rural studies, London: SAGE, pp. 104-122.

Light I., Bhachu P., Karageorgis S., 2004. Migration networks and immigrant entrepreneurship [in:] I. Light, P. Bhachu (eds.), Immigration and 
entrepreneurship: Culture, capital, and ethnic networks, New Jersey: Transaction Publishers, pp. 25-49.

Mayer H., Habersetzer A., Meili R., 2016. Ruralurban linkages and sustainable regional development: The role of entrepreneurs in linking peripheries and centers. Sustainability, vol. 8 , no. 8, 745; https://doi.org/10.3390/su8080745.

Ministry of Agriculture of the Czech Republic, 2018. Rural Development Programme of the Czech Republic for the period 2014-2020, Version 6.2.

Moseley M.J., 2003. Rural development: Principles and practice. Thousand Oaks (California): Sage.

MURDOCH J., 1992. Representing the region: Welsh farmers and the British state [in:] T. Marsden, P. Lowe, S. Whatmore (eds.), Labour and Locality: uneven development in the labour process, London: David Fulton, pp. 160-181.

Newbery R., Siwale J., Henley A., 2017. Rural entrepreneurship theory in the developing and developed world. The International Journal of Entrepreneurship and Innovation, vol. 18, no. 1, pp. 3-4.

North D., Smallbone D., 2006. Developing entrepreneurship and enterprise in Europe's peripheral rural areas: Some issues facing policy-makers. European Planning Studies, vol. 14, no. 1, pp. 41-60.

Novotná M., 2013. Formy podnikání amentních migrantů na venkově [in:] K. Mičudová (ed.), Trendy v podnikání 2013, Plzeň: Západočeská univerzita v Plzni, 1st edn., 6 pp.

OuŘedníček M., Novák J., ŠIMON M., 2013. Současné změny migrační bilance nejmenšich českých obcí [in:] Výroční konference České geografické společnosti. Nové výzvy pro geografii, Brno: Masarykova univerzita, pp. 246-255.

PĚLUCHA M., KVĚTOŇ V., 2017. The role of EU rural development policy in the neoproductivist agricultural paradigm. Regional Studies, vol. 51, no. 12 , pp. 1860-1870.

Pí̌A J., 2019. The lawn grew too quickly! Perception of rural idyll by Czech amenity migrants. GeoScape, vol. 12, no. 1.
PtazIAK M., Rachwat T., 2014. The role of entrepreneurship in regional development strategies (based on the Polish National Strategy of Regional Development 2010-2020). Europa XXI, vol. 26, pp. 97-110.

PospěCH P., 2014. Discursive no man's land: Analysing the discourse of the rural in the transitional Czech Republic. Journal of Rural Studies, vol. 34, pp. 96-107.

Ray C., 2006. Neo-endogeneous development [in:] P. Cloke, T. Marsden, P. Mooney (eds.), Handbook of rural studies, London: Sage, pp. 278-292.

ROWLEY T., 2003. The rural identity crisis. Rural Policy Research Institute, www.rupri.org.

Smallbone D., 2009. Fostering entrepreneurship in rural areas [in:] J. Potter, A.R. Hofer (eds.), Strengthening entrepreneurship and economic development in East Germany: Lessons from local approaches, Paris: Organisation for Economic Co-operation and Development, pp. 161-187.

StoCKDAle A., 2006. Migration: Pre-requisite for rural economic regeneration? Journal of Rural Studies, vol. 22, no. 3, pp. 354-366.

StOCKDAlE A., 2014. Unravelling the migration decision-making process: English early retirees moving to rural mid-Wales. Journal of Rural Studies, vol. 34, pp. 161-171.

ŠIMON M., 2014. Exploring counterurbanisation in a post-socialist context: Case of the Czech Republic. Sociologi Ruralis, vol. 54, no. 2, pp. 117-142.

ŠImON M., Bernard J., 2016. Rural idyll without rural sociology? Changing features, functions and research of the Czech countryside. Eastern European Countryside, vol. 22, no. 1, pp. 53-68.

Van Der Ploeg J.D., Renting H., Brunori G., Knickel K., Mannion J., Marsden T., Roest K.D., Sevilla-Guzmán E., Ventura F., 2000. Rural development: From practices and policies towards theory. Sociologia Ruralis, vol. 40, no. 4, pp. 391-408.

Woods M., 2011. Rural. London: Routledge. 